\title{
Geophysics Contribution for the Determination of Aquifers with a Case Study
}

\author{
Latifa Ouadif $^{1}$, Lahcen Bahi ${ }^{1}$, Ahmed Akhssas ${ }^{1}$, Khadija Baba ${ }^{1}$, Med Menzhi ${ }^{2}$ \\ ${ }^{1}$ G GIE Laboratory, Mohammadia Engineering School, Mohammed V Agdal University, Rabat, Morocco \\ ${ }^{2}$ National Centre for Scientific and Technical Research, Mohammed V Souissi University, Rabat, Morocco \\ Email: ouadif@gmail.com
}

Received September 24, 2011; revised November 23, 2011; accepted December 29, 2011

\begin{abstract}
The determination and monitoring of aquifer formations on the eastern border of Moroccan Gharb basin are very difficult because of their spatial and temporal variation. To delimit these formations, a geophysical survey of 52 geoelectric soundings was performed with a mesh of $500 \mathrm{~m}$ and electrodes distance between $1000 \mathrm{~m}$ and $3000 \mathrm{~m}$. Geoelectric sections and resistivity maps show a horst and graben structure. The correlation of existing oil drillings shows that the Jurassic and Neogene formations are both affected by normal faults causing Jurassic deposits collapse with local thickening of the Miocene deposits, and reverse faults delimiting tectonic slices due to tension caused by prerifaine nappe advance. This fact confirms the generated structure by the resistivity method. The isobath map of resistant formations's roof show average depths extending from 400 to $800 \mathrm{~m}$ for calcareous sandstone that are potential aquifers while oil drillings indicate over $1000 \mathrm{~m}$ depths.
\end{abstract}

Keywords: Aquifer; Prerifaine Nappe; Resistivity Method; Geophysical Survey; Gharb Basin

\section{Introduction}

The Gharb Neogene basin is a collapse zone formed on the margins of the Rif's chain. The filling deposits of the basin are characterized by a vertical variation due to a regional geological context. The Gharb basin, which knew many subsidences during certain periods, with a paroxysm in the Pliocene, receives the prerifaine nappe which subdivides the Miocene in infra-nappe and supra-nappe Miocene [1-5]. The former works reflect the structural complexity of Gharb basin in general and particulary its eastern boundary. This makes the determination and monitoring of the formations, constituted by permeable deposits likely to correspond to aquiferous levels, very difficult [6-8]. The recognition of this limit is confronted with the difficulties posed by the lack of data and controversial interpretations about the structure of this limit $[9,10]$. Thus, it is necessary to conduct synthetic studies implying local geology, study of oil drillings and interpretation of all carried out geoelectric soundings. The realization of geoelectric sections and resistivity maps, combined with the correlations of stratigraphic drilling columns, allows elucidating the structure of the eastern boundary of the Gharb basin-prerifaine ridges which is affected by reverse faults due to prerifaine nappe advance in the basin and by the collapse normal faults.

\section{Methodology}

The study purpose is to identify the major tectonic aspects of the eastern border of the Gharb basin with prerifaine ridges and find out the formations that may constitute potential aquifers levels. This approach required the interpretation of 52 geoelectric soundings with $\mathrm{AB}$ electrodes distance varying from 1000 to $3000 \mathrm{~m}$, carried out in the Sidi Kacem region, and also to study the oil drills data in the same region that have provided a database on the petrographic facies of the Jurassic and Neogene deposits of the basin boundary with prérifaines ridges. North EasSouth West and North-South drillings correlations show lateral and vertical various formations evolution of this complex boundary.

The electrical resistivity method is most used in engineering geology. It identifies and locates, from the earth surface, the structures which have resistivity contrasts $[11,12]$. It consists of conducting geoelectric sounding to determine, at several points, the vertical succession of layers of different resistivity. This method is based on the principle of Ohm's law: the injection in soil of a direct current at a very low frequency and then voltage measurement makes it possible to unveil the true resistivity of crossed formations. Several devices were used among which the most known is the Schlumberger one. In this device (Figure 1), we inject a current into two electrodes 
$\mathrm{A}$ and $\mathrm{B}$, and we measure the voltage at the receiving electrodes $\mathrm{M}$ and $\mathrm{N}$. Apparent resistivity is given by:

$$
\rho_{\text {app }}=\pi \frac{\left(L^{2}-l^{2}\right)}{2 l} \frac{\Delta V}{I} \text { or } \rho_{\text {app }}=K \frac{\Delta V}{I}
$$

where $K$ is the geometric factor that depends on electrodes spacing only.

Our geophysical survey covers an area of $20 \mathrm{~km}^{2}$ and includes 52 geoelectric soundings with a line $\mathrm{AB}$ length extending from 1000 to $3000 \mathrm{~m}$ (Figure 2). We interpreted these VES to determine the vertical succession of formations in place and have made geoelectric sections to

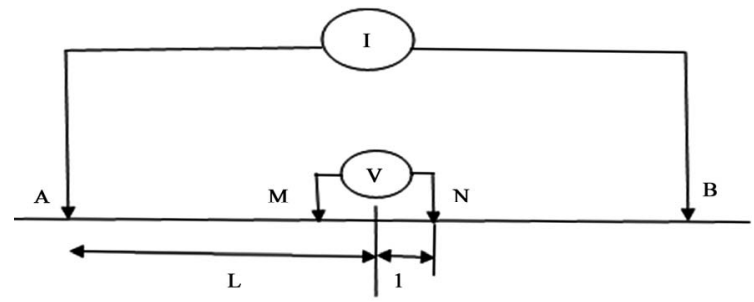

Figure 1. Schlumberger array. show the lateral variation of facies. We have also made geological sections from oil drilling combined with geoelectric sections to correlate the different data and better approximate the limit structure between the prerifaines ridges and the Gharb Basin.

\section{Results and Discussions}

\subsection{Geoelectric Soundings Interpretation}

Inverse modeling of the electrical resistivity data is done using the software IPI2WIN [13]. We distinguish four groups of geoelectric soundings that generally show respectively from top to bottom the following (Figure 3).

Group 1 (Figure 3(a)):

A thin clay layer;

Sand with $60 \mathrm{~m}$ of average thickness;

Thick layer of marl up to $400 \mathrm{~m}$;

Resistant layer formed by calcareous sandstone of the Miocene.

Group 2 (Figure 3(b)):

A thin clay layer;

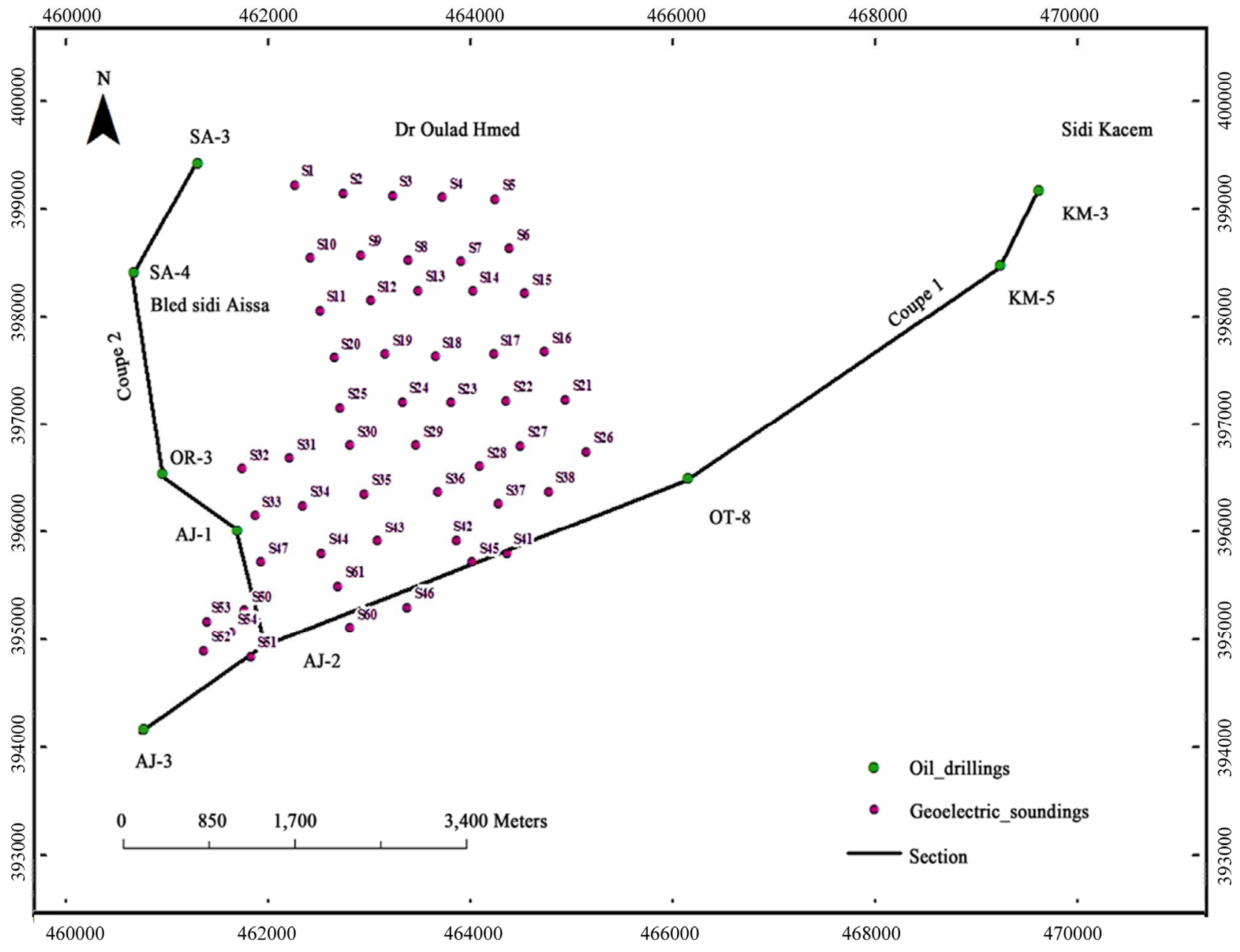

Figure 2. Location map of geoelectric soundings. 


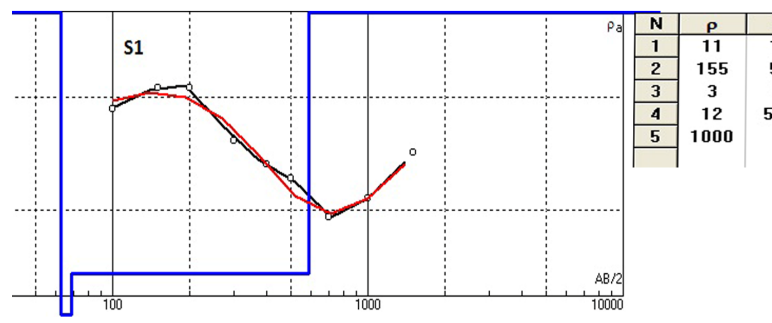

(a)

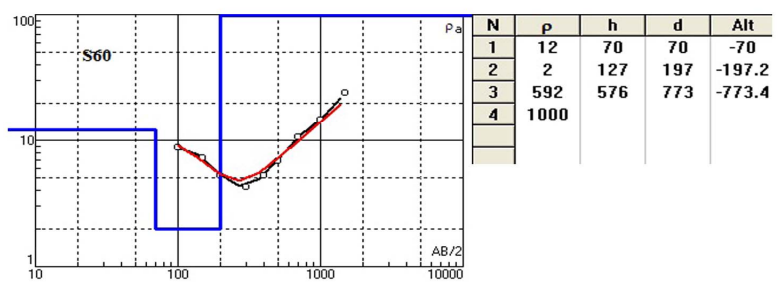

(c)

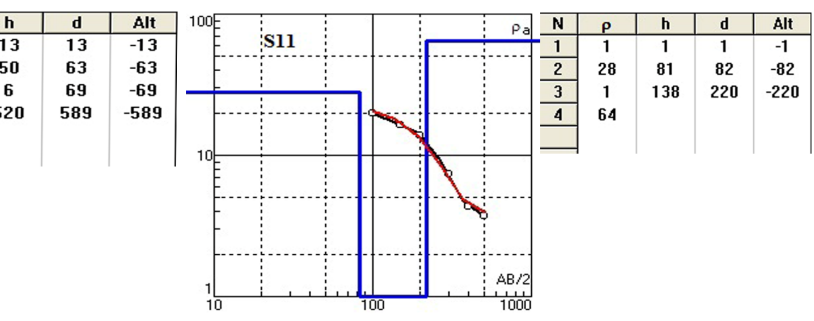

(b)

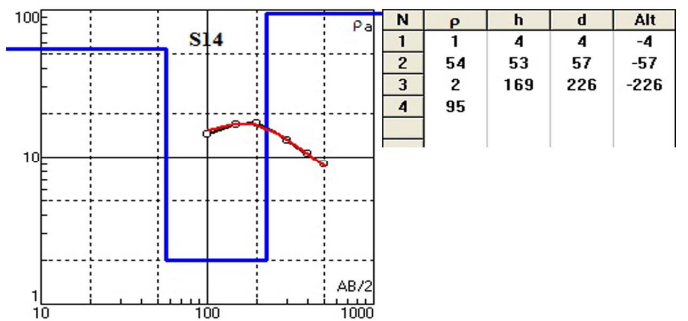

(d)

Figure 3. Interpretation of some geoelectric soundings.

A low resistance formation assigned to marly sands; A marly formation becomes a little stronger at depth; These geoelectric soundings have not reached the resistant sandstones of the Miocene.

Group 3 Figure 3(c):

A thin resistant cover made of conglomerates;

Formations of sand little resistant;

Marly formations that reach a depth of $150 \mathrm{~m}$;

A resistant formation formed by sandstone is reached at a shallow depth of about $200 \mathrm{~m}$.

Group 4 Figure 3(d):

Thin clay formation;

Sixty meters of sand and marl, which become stronger at depth.

These geoelectric soundings have not reached the calcareous sandstone.

\subsection{Geoelectric Cross Section}

The Neogene basin of the Gharb has become deformed at its borders what is due to tectonic movements of the Prerif and prerifaines ridges [14-17]. Geoelectric sections based on data from geoelectric soundings performed in two directions to identify the shape and structure of the border: A subparallel direction North East-South West to the ridge of Outita-Draa (Figure 4) and a North West-South East direction which is perpendicular to the ridge (Figure 5).

The subparallel sections to the ridge show resistant formations with shape of horst and graben that sink deep leaving place for marly Neogene deposits. These marly deposits are very thick reaching $500 \mathrm{~m}$ in S4 in north of the study area.

The perpendicular sections to the ridge also show the same structure of horst and graben. Approaching the ridge, the resistant complex is shallower; it is reached at $300 \mathrm{~m}$.

\subsection{Structural Analysis}

The structural analysis is based on the study of oil drillings. North East-South West correlations drillings show that the Jurassic and Neogene formations are affected by normal faults which cause a collapse of both sides of an upper area formed by Jurassic deposits (boreholes OT8 and KM5) with thickening of the Miocene, and reverse faults that delimit a tectonic slices. These reverse faults are mainly due to tension caused by the advance of the prerifaine nappe in the Neogene Gharb basin. However the geoelectric soundings show the heterogeneity of formations met in the south-east Jurassic ridge, which demonstrates the complexity of this area which is affected by normal and reverse faults delimiting horsts and grabens (Figure 6).

The North-South correlations, also, show a thickening of the Miocene at the areas of collapse that is progressif from Outita link in South towards North in direction of center of Gharb basin. Reverse faults affecting the prerifaine nappe and Miocene deposits result from the deformation caused by the advance of the prerifaine nappe in Gharb basin (Figure 7).

\subsection{Map Resistivity}

The Resistivity maps for different lengths of lines $A B$ also show the existence of faults and raising of Miocene marls which are conductives to the center of our area in a direction North West-South East (Figure 8). The resistivity map for $A B=200 \mathrm{~m}$ indicates that the surface formations are mainly marly except at the far North West where we are seeing more resistant formations that can be attributed to the sandy sandstone. The greater the length 
of line $A B$, where we reaches deeper formations [18,19], the most of Miocene marls appear in the middle of our zone in a North West-South East direction. This confirms once again this tectonic as a horst and graben.

The depth distribution map of the roof of the resistant complex which may constitute a potential aquifer shows that he is reached as lenses at shallow depths around 200 $\mathrm{m}$ in the central zone and the Far East. At South East, it is at great depths reaching $800 \mathrm{~m}$, while in the rest of the area, it is reached at an average depth between 400 and

\section{$600 \mathrm{~m}$ (Figure 9).}

\section{Conclusion}

Gharb Basin has been the subject of several geological, geophysical and sedimentological studies; however, the eastern boundary of the basin remains unknown. The geoelectric survey has shown the geological complexity of this boundary. The geoelectric sections and resistivity maps show a structure in horst and graben. Oil drillings

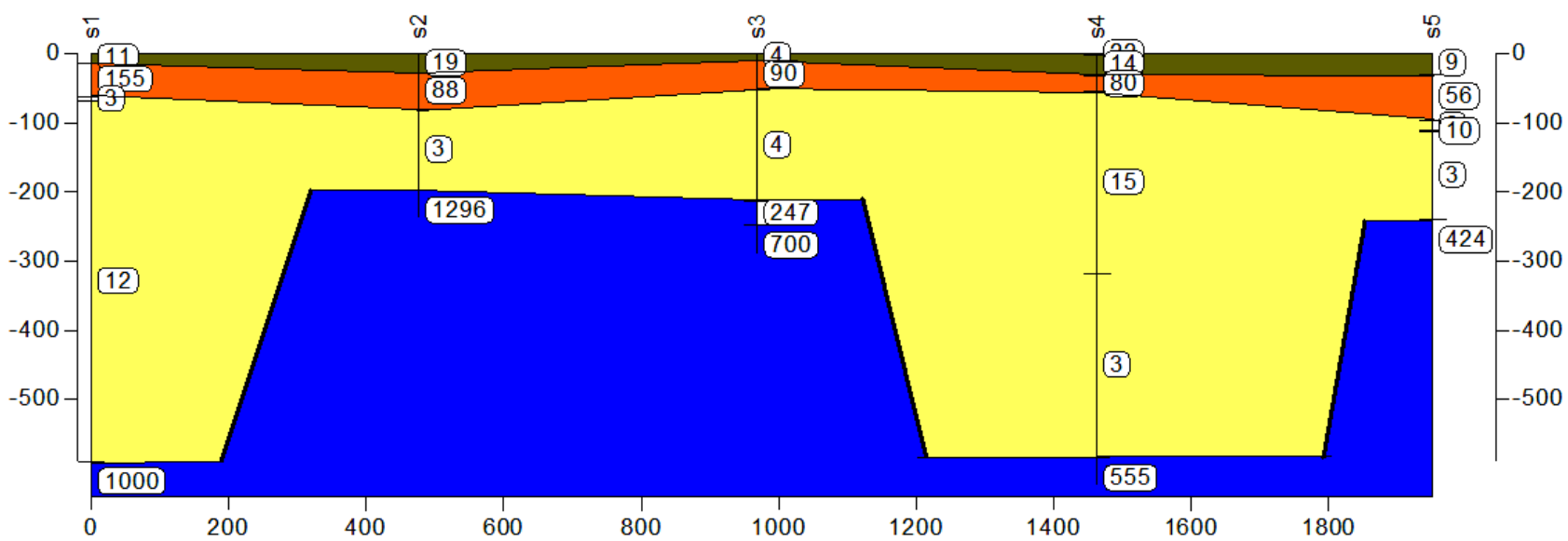

(a)

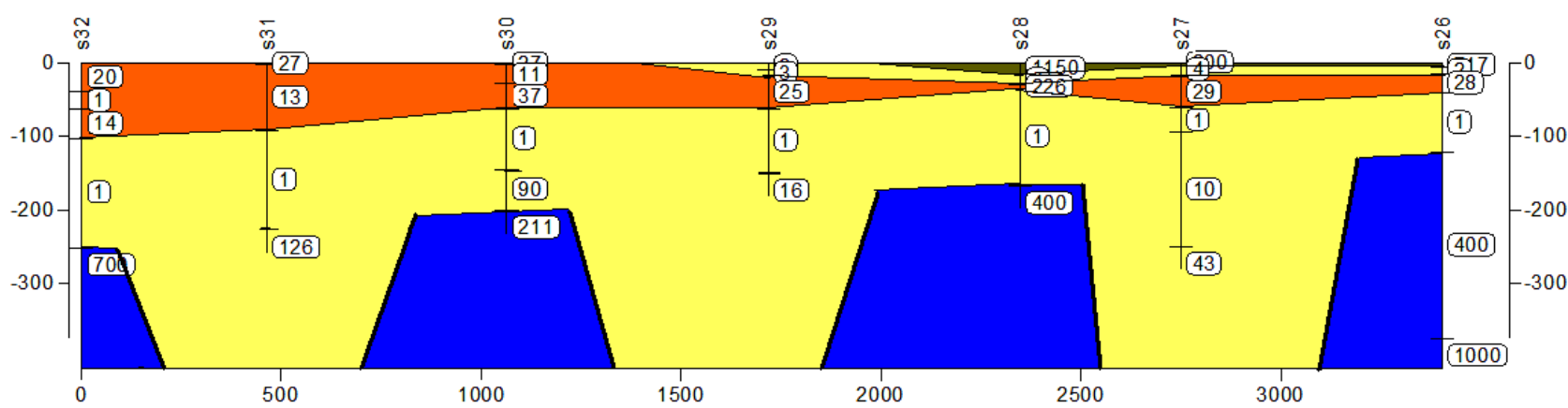

(b)

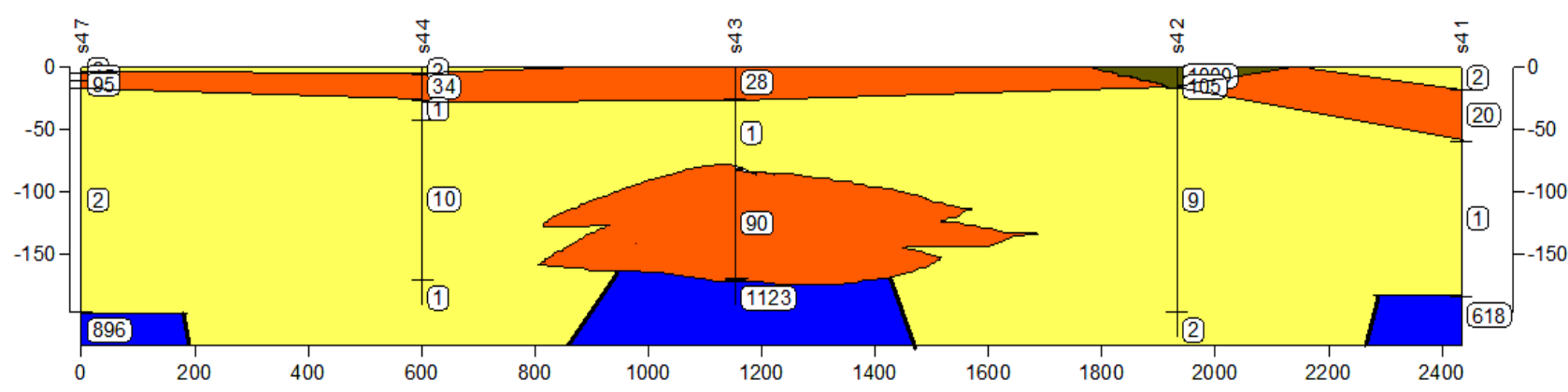

(c)

Conglomerate

Sand

Marl

Neogene limestone

Figure 4. North East-South West geoelectric sections, subparallel to Outita-Draa ridge. 


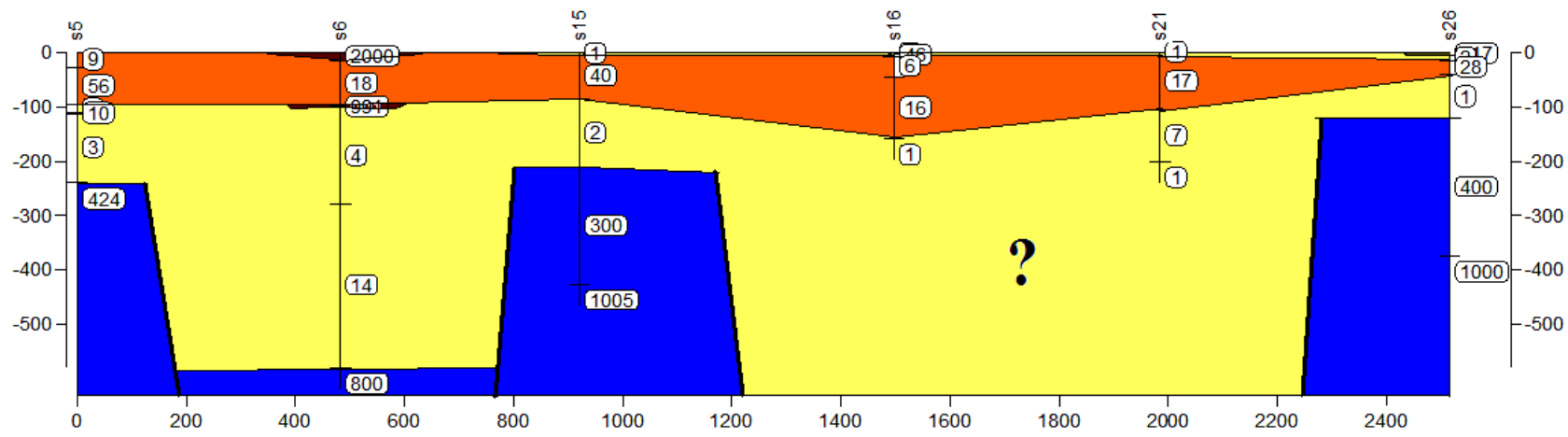

(a)

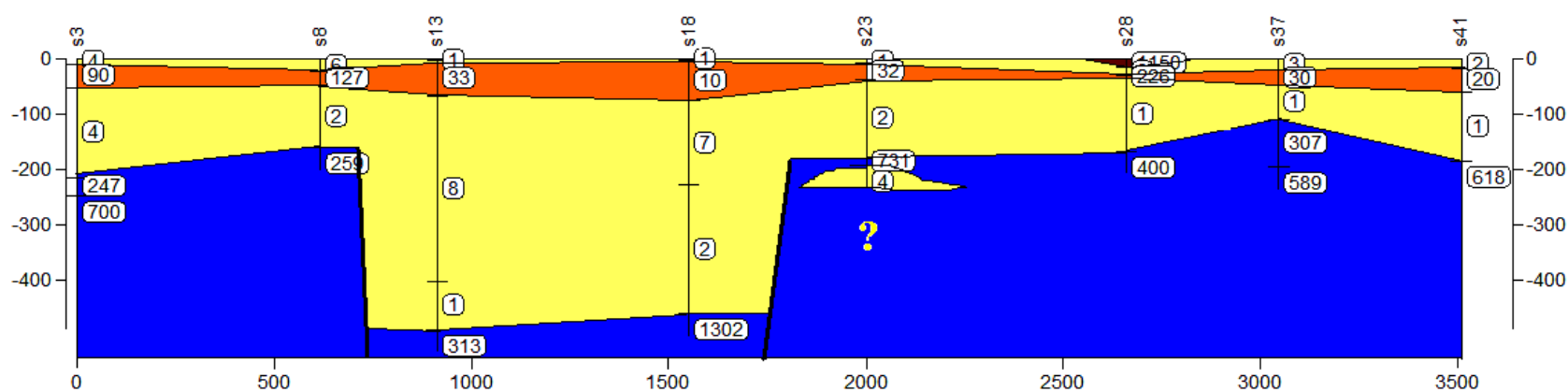

(b)

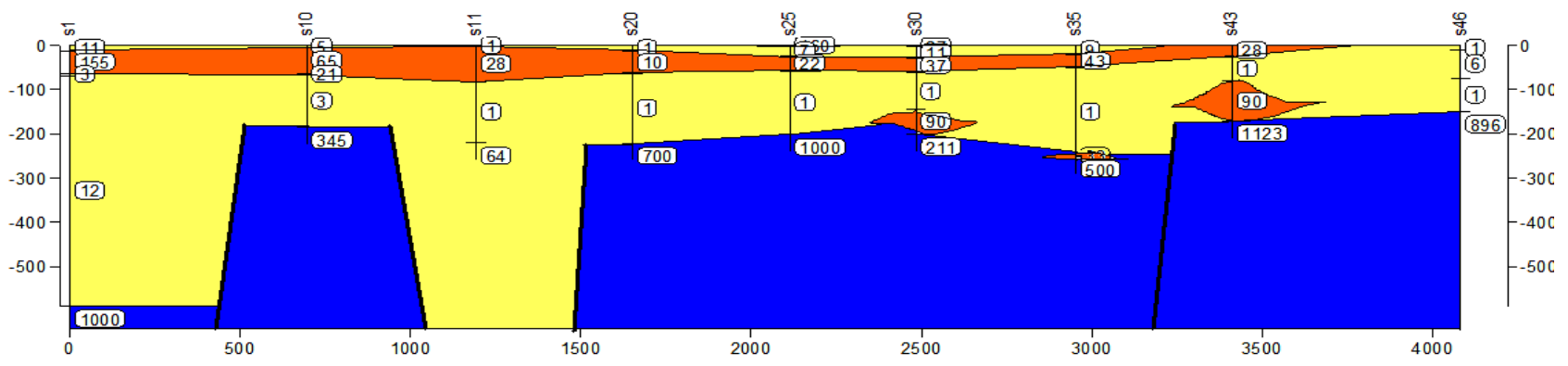

(c)

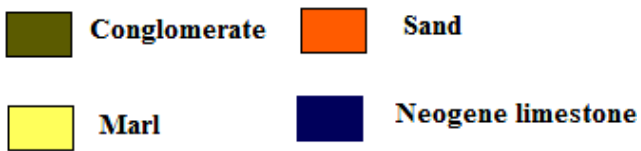

Figure 5. North Weast-South East geoelectric sections, perpendicular to Draa Outita ridge.

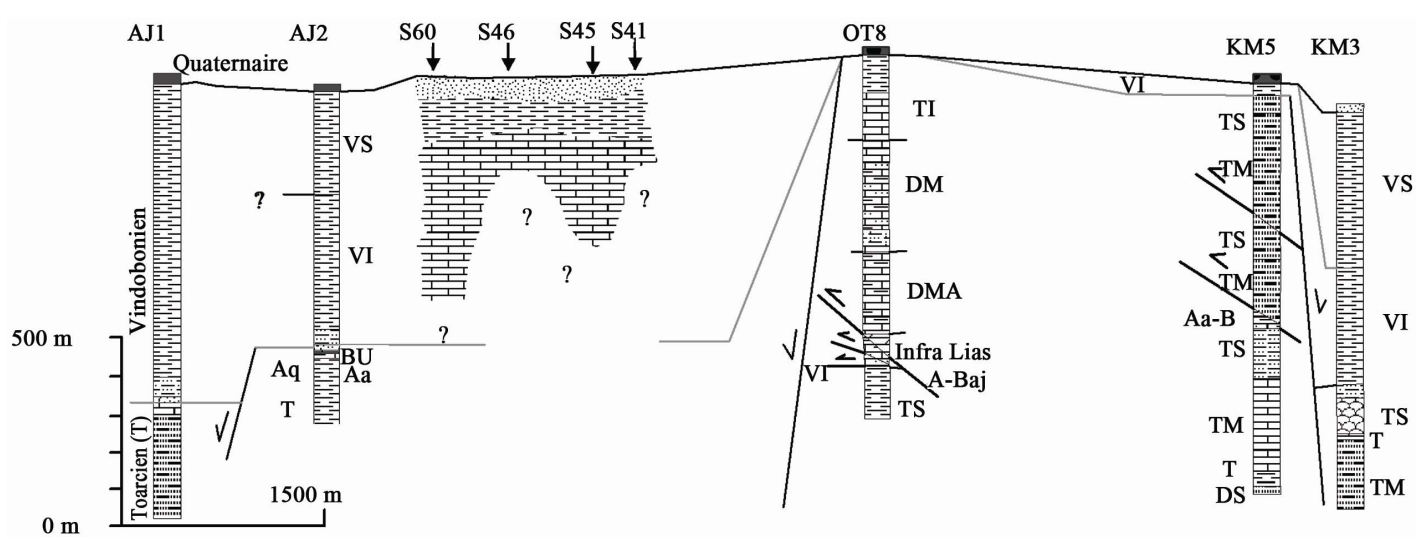

Figure 6. North East-South West geological and geoelectric sections. 


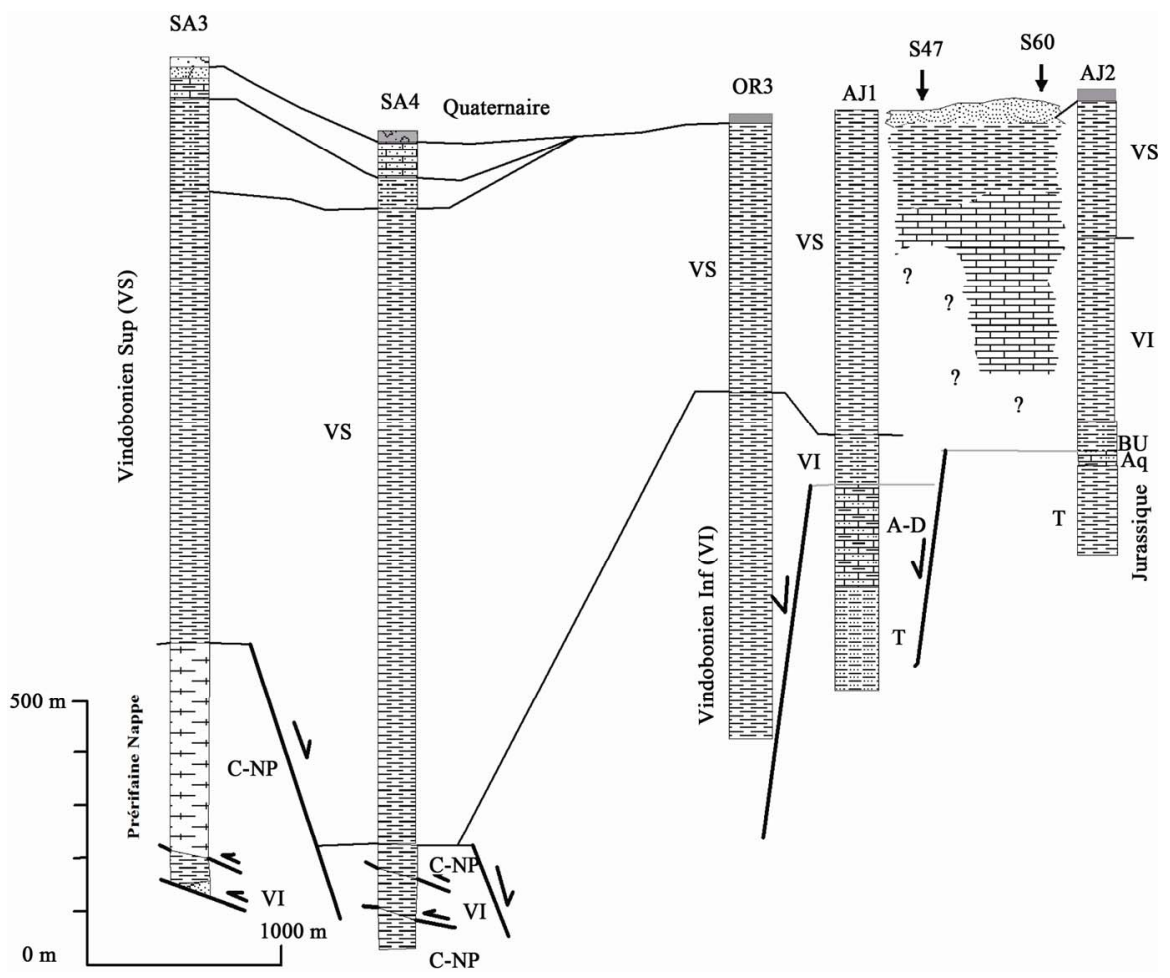

Figure 7. North South geological and geoelectric sections.

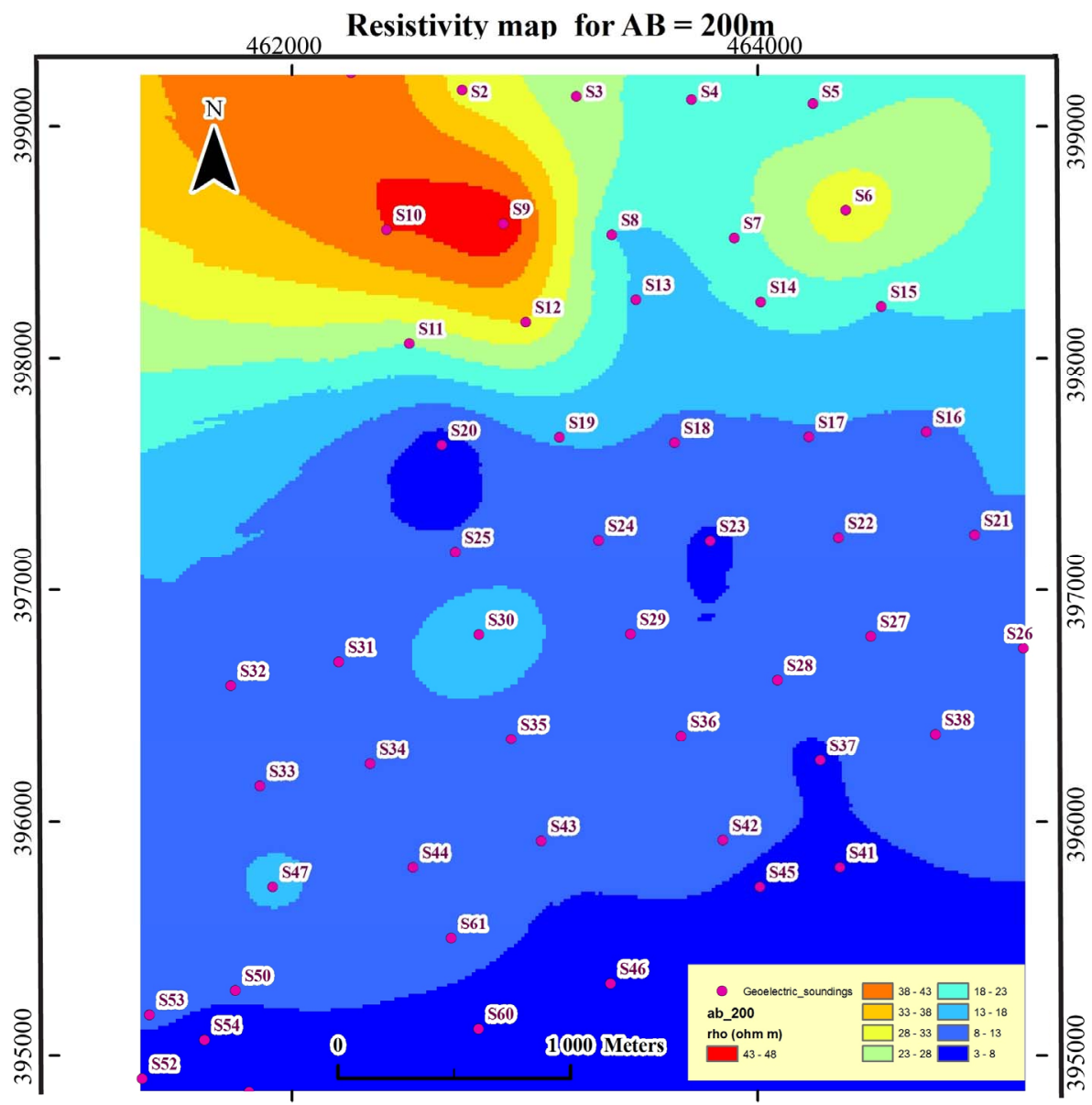


Resistivity map for $\mathrm{AB}=600 \mathrm{~m}$
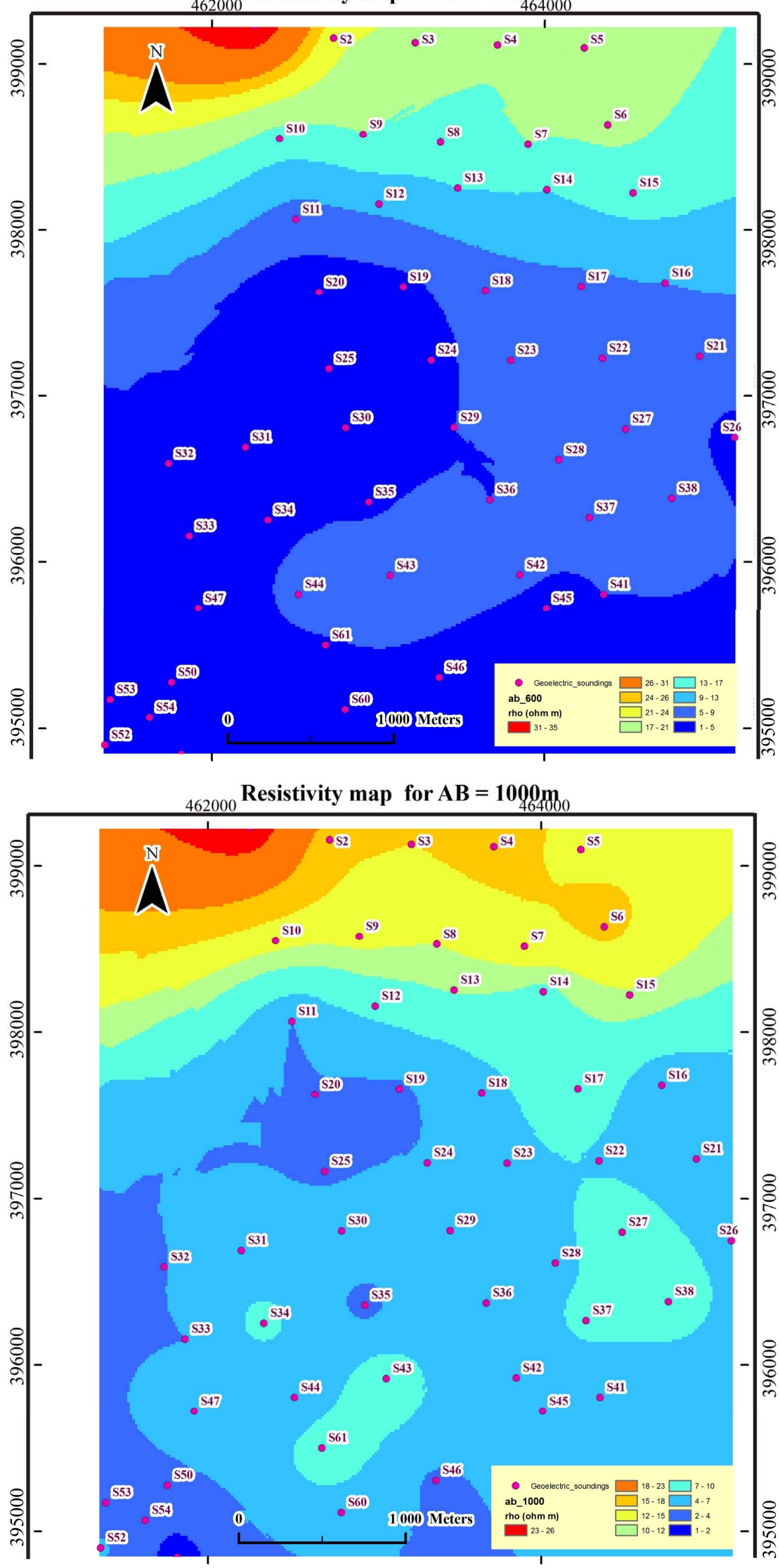


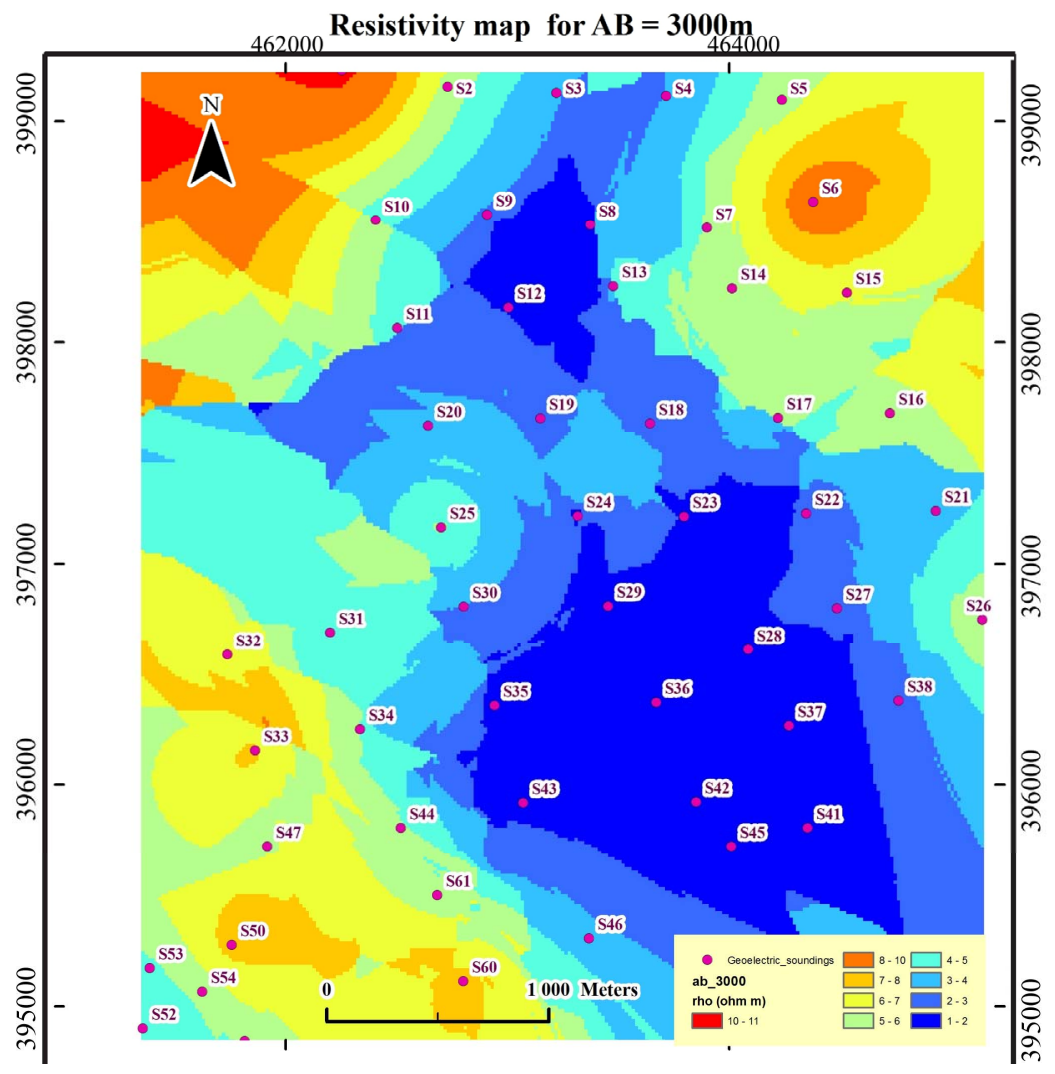

Figure 8. Resistivity maps for $\mathrm{AB}=$ 200, 600, 1000 and 3000 .

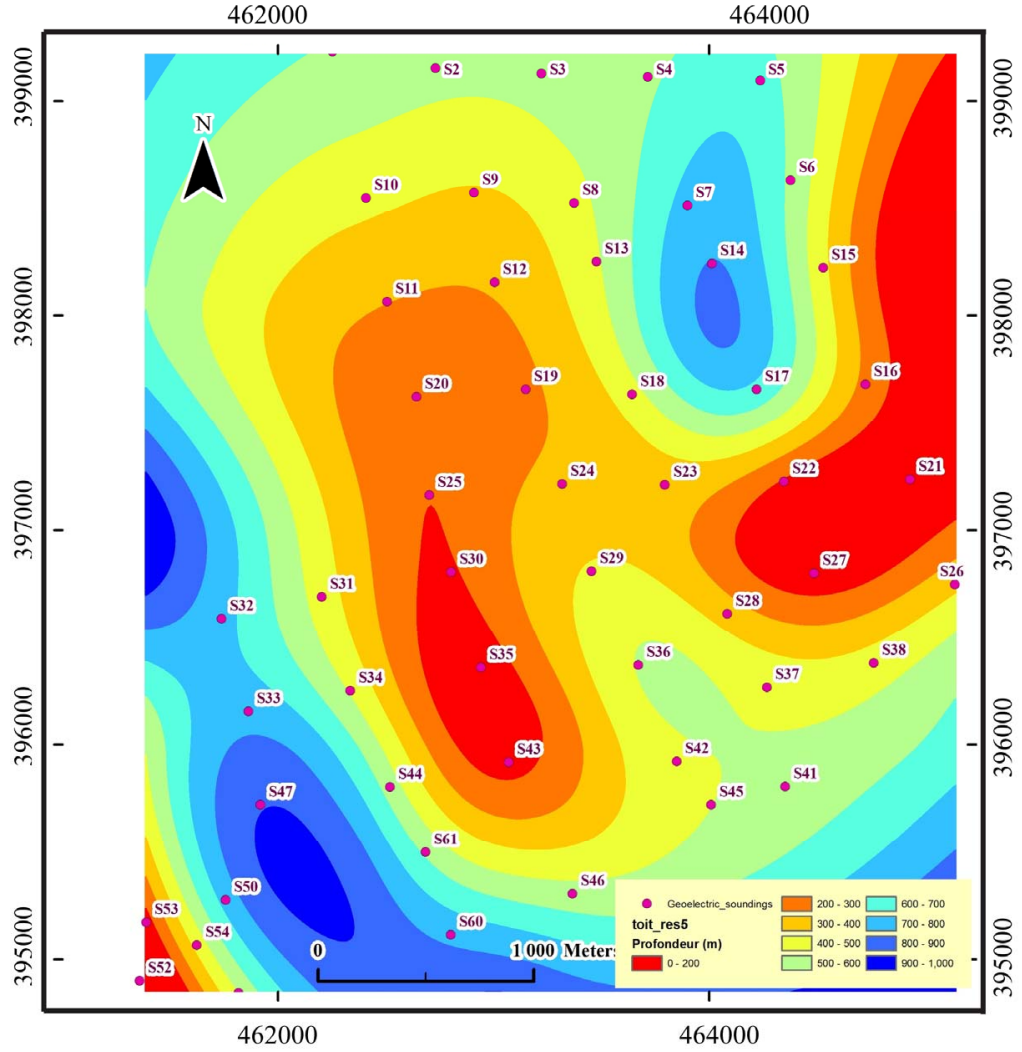

Figure 9. Depth distribution map of resistant roof. 
correlations conducted in Sidi Kacem region show reverse faults affecting the Jurassic and the Neogene due to tension caused by the prerifaine nappe advance. This confirms the structure generated by the geoelectric survey. The originality of our work is the fact that the roof map of resistant layers gives average depths between 400 and $600 \mathrm{~m}$ for calcareous sandstone which could constitute potential aquifers as opposed to the oil drillings, which indicate depths over $1000 \mathrm{~m}$.

\section{REFERENCES}

[1] P. Cirac, "Le Bassin Sud-Rifain Occidental au Néogène Supérieur. Evolution de la Dynamique Sédimentaire et de la Pléogéographie au Cours d'Une Phase de Comblement," Thèse d'Etat, Université de Bordeaux I, 3 Tomes, 1985.

[2] P. Cirac, "Environnements Sédimentaires du Pliocène de la Bordure Pré-Rifaine du Gharb (Maroc Nord-Occidetal)," Bulletin de la Société Géologique de France, Vol. 7, No. 3, 1978, pp. 3323-3327.

[3] H. Feinberg, "Les Séries Tertiaires des Zones Externes du Rif (Maroc)," Notes et Mémoires du Service Géologique du Maroc, Vol. 315, 1986, p. 192.

[4] W. Litto, “Apport de la Sismique Réflexion et des Diagraphies à l'Etude de l'Evolution Géodynamique D'un Bassin Néogène à Potentiel Pétrolier: Exemple de la Marge Nord du Bassin du Gharb (Avant Pays Rifain, Maroc)," Thèse de Doctorat, Faculté des Sciences Rabat, Maroc, 2001.

[5] Société Chérifienne des Pétroles (SCP), "Carte Géologique du Gharb et Prérif Occidental, 1/200000,” 1952.

[6] A. Akhssas, “Contribution à l'Etude des Niveaux Sableux à Hydrocarbures du Miocène Post-Nappe du Bassin du Gharb (Maroc). Application de l'Analyse Multidimensionnelle," Thèse d'Etat, University Mohammed V-Agdal, 2002.

[7] M. Boutakiout, "Les Foraminifères Jurassiques des Rides sud Rifaines et des Régions Voisines (Maroc)," Thèse d'Etat, Université Lyon, 1988.

[8] M. Kili, B. El Mansouri, J. Chao and A. Ait Fora, "De Nouveaux Eléments Structuraux du Complexe Aquifère Profond du Bassin du Rharb (Maroc),"'Comptes Rendus Geoscience, Vol. 338, No. 16, 2006, pp. 1194-1202. doi:10.1016/j.crte.2006.09.008

[9] A. Tahayt, T. Mourabit, A. Rigo, K. L. Feigl, A. Fadil, S. McClusky, R. Reilinger, et al., "Mouvements Actuels des Blocs Tectoniques dans l'arc Bético-Rifain à Partir des Mesures GPS Entre 1999 et 2005,"Comptes Rendus Geoscience, Vol. 340, No. 6, 2008, pp. 400-413. doi:10.1016/j.crte.2008.02.003

[10] N. Maad, P. Le Roy, et al., "Seismic Stratigraphy of the NW Moroccan Atlantic Continental Shelf and Quaternary Deformation at the Offshore Termination of the Southern Rif Front," Comptes Rendus Geoscience, Vol. 342, No. 9, 2010, pp. 731-740. doi:10.1016/j.crte.2010.04.006

[11] T. Chouteau, "Les Méthodes Electriques," Notes de Cours, Publications Ecole Polytechnique, Montréal, 2001.

[12] W. M. Telford, L. P. Geldart, R. E. Sheriff and D. A. Keys, "Prospection Géophysique, Tome 3," La Barbannerie, 1989.

[13] GEOSCAN-M Ltd., "IPI2Win v.2.1, IPI_Res2, IPI_Res3," User's Guide, 2001.

[14] K. Bargach, P. Ruano, A. Chabli, J. Galindo-ZaldiVar, A. Chalouan, A. Jaboloy, M. Akil, M. Ahmamou, C. Sanz De Galdeano and M. Benmakhlouf, "Recent Tectonic Deformations and Stresses in the Frontal Part of the Rif Cordillera and the Saiss Basin (Fes and Rabat Regions, Morocco," Pure and Applied Geophysics, Vol. 161, No. 3, 2004, pp. 521-540. doi:10.1007/s00024-003-2461-6

[15] J. C. Faugères, “Les Rides Sud-Rifaines. Evolution Sédimentaire et Structurale d'un Bassin Atlantico-Mésogéen de la Marge Africaine," Thèse de Doctorat d'Etat, 2 Tomes, Université Bordeaux I, 1978

[16] W. Litto, B. Jaaidi El, M. Dakki and F. Et Medina, "Evolution Sédimentologique et Structurale de la Marge Nord du Bassin du Gharb Durant le Néogène (Avant Pays Rifain, Maroc): Cas d'une Inversion," XIth Congress of Regional Committee on Mediterranean Neogene Stratigraphy, 27-30 September 2000.

[17] M. Zizi, "Triassic-Jurassic Extensional Systems and Their Neogene Reactivation in Northern Morocco (The Rides Prerifaines and Guercif Basin)," Ph.D. Thesis, Rice University, Houston, 1996.

[18] P. Kearey, M. Brooks and I. Hill, "An Introduction to Geophysical Exploration," Blackwell Science Ltd, Malden, 2002.

[19] C. Meyer de Stadelhofen, “Applications de la Géophysique aux Recherches d'Eau," Lavoisier, 1991. 